\title{
An Efficient Mapping Tool Development for University Campuses: The Case Study of Süleyman Demirel University
}

\author{
Mustafa BATAR \\ Burdur Mehmet Akif Ersoy University, Department of Computer Engineering, 15030, Burdur \\ Geliş Tarihi (Received): 06.10.2021, Kabul Tarihi (Accepted): 06.11.2021 \\ $\square$ Sorumlu Yazar (Corresponding author*): mbatar@mehmetakif.edu.tr \\ (C) +902482132754 贾 +902482132704
}

\begin{abstract}
The main purpose of this study is to design and develop "Süleyman Demirel University Campus Maps system (SDU Campus Maps)" with geographic information systems in order to create a campus information system. By the contribution of SDU Campus Maps, which is planned to be carried out, directions will be provided from one point to another within the university, and it will be convenient for visitors who do not know about Süleyman Demirel University campus. With this idea, it is based on the preparation of the environment so that directions can be made using the SDU campus map. With the help of this study, it has been aimed to provide contribution to the literature of both geographic information systems and mapping.
\end{abstract}

Keywords: Application software, geographic information systems (GIS), mapping

\section{Üniversite Yerleşkeleri İçin Etkin Bir Haritalama Aracı Geliştirilmesi: Süleyman Demirel Üniversitesi Örneği}

Öz

Bu çalışmanın temel amacı, bir kampüs bilgi sistemi oluşturma hedefine yönelik olarak coğrafi bilgi sistemleri ile "Süleyman Demirel Üniversitesi Kampüs Maps sistemi (SDÜ Campus Maps)" oluşumunun tasarlanması ve bir pilot proje şeklinde gerçekleştirilmesidir. Tasarlanıp uygulanması düşünülen SDÜ Campus Maps ile üniversite içerisinde bir noktadan başka bir noktaya yol tarifi yapılabilecek ve Süleyman Demirel üniversitesi yerleşkesini bilmeyen ziyaretçilere kolaylık sağlanmış olacaktır. Bu düşünce ile SDÜ yerleşke haritası kullanılarak yol tarifi yapılabilmesi için ortamın hazırlanması esas alınmıştır. Geliştirilen bu uygulama ile coğrafi bilgi sistemleri alan-yazınına önemli katkıları olacağı açıkça gösterilmeye çalışılmıştır.

Anahtar Kelimeler: Uygulama yazılımı, coğrafi bilgi sistemleri (CBS), haritalama

\section{INTRODUCTION}

The importance of knowledge will be understood by today's societies, that our age has been called "information age" and countries have entered into a great race in this regard (Çağatay, 2012). It is now the way to make the best use of the information that is accepted as a resource. The importance of knowledge on social developments is that a transformation that influences each logical discipline as much as the entire society, association and individuals on the planet is testing us. The social orders that will be generally influenced by this interaction, which is characterized as the data age, will be nations like Turkey, which have not yet finished their turn of events. The impacts of the data age will be found in the social, social and financial 
existences of social orders instead of being specialized. To clarify the social responses made by these impacts, embrace philosophical and logical methodologies on this issue (Çağatay, 2012).

As in every field, it is necessary to use information effectively by making maximum use of information in the implementation of map-supported applications. To achieve this, it will be sufficient to use today's information technology in these areas. In particular, location-dependent graphical and non-graphical written information, which is described as map information, needs to be integrated within a system. However, in this way, there will be a fast and healthy access to the information to be stored (Aydınlıoğlu, 2010).

Geographical information systems (GIS) exists as an important technological tool that provides mapping and routing to the users today. GIS, which has found a wide application area, has started to be used intensively in our country. The benefits of GIS, which will be better understood as a result of current practices, should be used especially by public institutions in our country, and other entrepreneurs should be encouraged in this regard. If universities are counted as the most prioritized institution in informing the society, it becomes clear that universities should be the institutions where information is used most efficiently today. For this reason, the planning and development of universities and the ability to carry out research tasks in addition to education and training depend on the healthy and rapid use of existing information. Evaluating and updating existing information and obtaining new information from them are also inevitable for university development (Akay and Bensghir, 2007).

Today, there are information technologies that allow all location-based information to be collected, stored, processed and presented to the user in the desired format. Geographic information systems are an important tool for these needs. The important thing is to manage information with a regular management organization. Universities need to create a campus information system based on information technology in order to serve in a modern way. In this study, the design and application of a geographic information system and an information system on a sample campus were examined, emphasizing how the basic infrastructure of such a system should be (Arca, 2012).

A university is defined as a teaching institution comprising of resources, organizations, schools and comparative establishments and units, which have logical independence and public lawful character, and lead significant level instruction, preparing, logical examination and distributions (Çömert, 2016). The word academy is also used for university-like institutions, the word is of Greek origin and means "scholars, writers, artists' board", "college". The basic components that make up the university are; Such as human (student/research./instructor/...), space (campus, classroom/class/laboratory/...), finance (required resource for the system to work), function (university's management approach). When all these elements come together appropriately, an effective university structure emerges in terms of research, education/training and practice (Çömert, 2016).

The campus information system for universities is a tool for collecting, transferring, storing, querying, analysing and presenting spatial data related to the university and its academic subunits (faculties, departments, etc.) to the computer environment, in order to increase the success by increasing the efficiency of education and training. It is a combination of hardware, software and geographic data brought together. Universities; education, food, library, conference, accommodation, sports, urban equipment, etc. located on campuses furnished with services. As a settlement, campuses where the university can provide its own needs are desired. The desired location for the campus is the one close to the outer part of the city. The reason for this is that the university needs different areas according to the increasing number of students and new developments (Çelik, 2011).

Information system applications for university campuses have been realized in many universities, especially in the world and in our country - Turkey (Gören and Ferguson, 2002). If some university information system studies are given in the following (Sönmez and Sarı, 2004).

UC Berkeley University (USA) has been a "coordination board" has been established on the use of the University library and campus management (İnan and İzgi, 2011). This committee was asked to conduct preliminary studies and make determinations for the team through needs analysis. The Board continues to exist. University of Cape Town (Republic of South Africa) (Church, 2002) has been providing basic support on campus was later found to be inadequate Technical University of Vienna (Austria) (Day, 2002) which has been the most comprehensive study obtained is this study in 1993. This study was created by considering university administrators and decision makers. This work, called HIPS, offers inquiry and analysis for "decision makers" (Youd, 1984). 
Istanbul Technical University has been an information system has been designed taking into account the campus topography (Jun, 2000). At Yıldız Technical University (Istanbul) (Pandey and Pathak 2014); data were collected about the buildings, roads, walls, sports fields, green areas, trees, parking areas on the campus and an object-oriented GIS was developed. Middle East Technical University (Ankara) has been made to transfer all the infrastructure map information of the university in the CAD and paper sheet environment to the GIS environment (Fonseca et al., 2002).

The term expressed as "Geography Information System (GIS)" is expressed as "Geography=Geography", "Information=Information", "System=System" and "Geographic Information System" in Turkey. It is known as GIS in Turkey with its abbreviation (Nurlu, 2000). Because the GIS user is from different disciplines, this concept is defined in different ways. GIS has aroused wide interest among those interested in spatial information around the world. Rapid changes in developments, especially commercial expectations, different practices and ideas cause a precise definition of GIS to be made (Koçak, 2009). Some definitions for GIS in Turkey are as follows (Çömert et al., 2016):

- A computer system that describes regions of the world, stores and uses data. The name given to specialist software and hardware used to associate graphic and written information without destroying it, and to access information that is required and to be interpreted through detailed inquiries. To collect, store and keep up to date graphic information such as current maps, zoning plans, cadastral, thematic maps and all other non-graphic information related to a certain geography in line with predetermined or developing purposes, and to make regular or irregular inquiries using this information, all necessary legal, organizational and technical regulations. A system that enables soil-based information to be entered into the computer environment, stored, processed, analysed and output (Aydınoğlu et al., 2010).

- GIS is a database system that enables the collection of planning or environmental data suitable for data analysis for the management of a region or city, preparation of plans, decision making and implementation of decisions. GIS is a tool for making legal, administrative and economic decisions. GIS is a base used for planning and development purposes, consisting of information about the land and information in a certain region on the one hand, and rules and techniques for the systematic compilation, updating and distribution of data on the other hand. GIS is an important decision and management support system that enables new interpretations by establishing relationships between geographical location and verbal information (Gümrükçüoğlu, 2003).

- Some definitions for GIS in the world are as follows: GIS is all of the tools that perform the functions of collecting, storing, querying, transferring and displaying data belonging to objects on earth for a specific purpose. GIS is a form of information management system for displaying general map information. GIS is a data system used for the management of urban, environmental and other planning data suitable for data analysis, planning and preparation, decision making and monitoring the implementation of decisions. GIS is a tool that stores and analyses geographic information in a computer environment. GIS is a system that collects, controls, processes, analyses and displays earth-referenced data (Gören and Ferguson, 2002).

In the light of all the definitions given above, Geographic Information Systems (GIS) (Geographical Information System = GIS) can be defined as all of the computer aided tools necessary to transform the landforms and the events occurring on the earth into maps and analyze them. GIS technology has the ability to combine common databases (Tecim, 1999). For example, the visual and geographic analysis advantages provided by maps are presented to the user as query and statistical analysis. In this feature, GIS is different from other information systems. As a result of this, GIS is used extensively by the public and private sectors in defining the events in the service area and making strategic plans that will make forward-looking forecasts. Map making and analysis of geographic data is not a new process. However, GIS can do such operations better and faster than it actually is (Yomralıoğlu, 2000; Yomralıoğlu, 2010). Prior to GIS technology, only certain individuals needed to use geographic information for decisionmaking and problem solving. Today, however, GIS employs many people in industry all over the world. GIS is taught in basic education schools, colleges and universities all over the world, and all professionals using geospatial information are working with geographic data more and more (Turoğlu, 2000). 


\section{MATERIAL AND METHODS}

Today, there are many application tools, in other words, software that can help create GIS. In the implementation of SDU Campus Maps, Maplnfo Professional, Visual Studio and MapInfo MapXtreme will be used to integrate the maps and data obtained with MapInfo into Visual Studio. With the program to be created with Visual Studio, users will be presented with a simple and useful user interface that is far from complexity. This situation has been tried to show in Figure 1.
The campus map, which was taken from SDU construction works as an Autocad file, was imported into Maplnfo with the contribution of Maplnfo's Universal Translate Tool. In other words, the file with the DWG extension has been converted to TAB files so that they could be used and applied easily in Maplnfo platform and tool. This structure has been given in Figure 2.

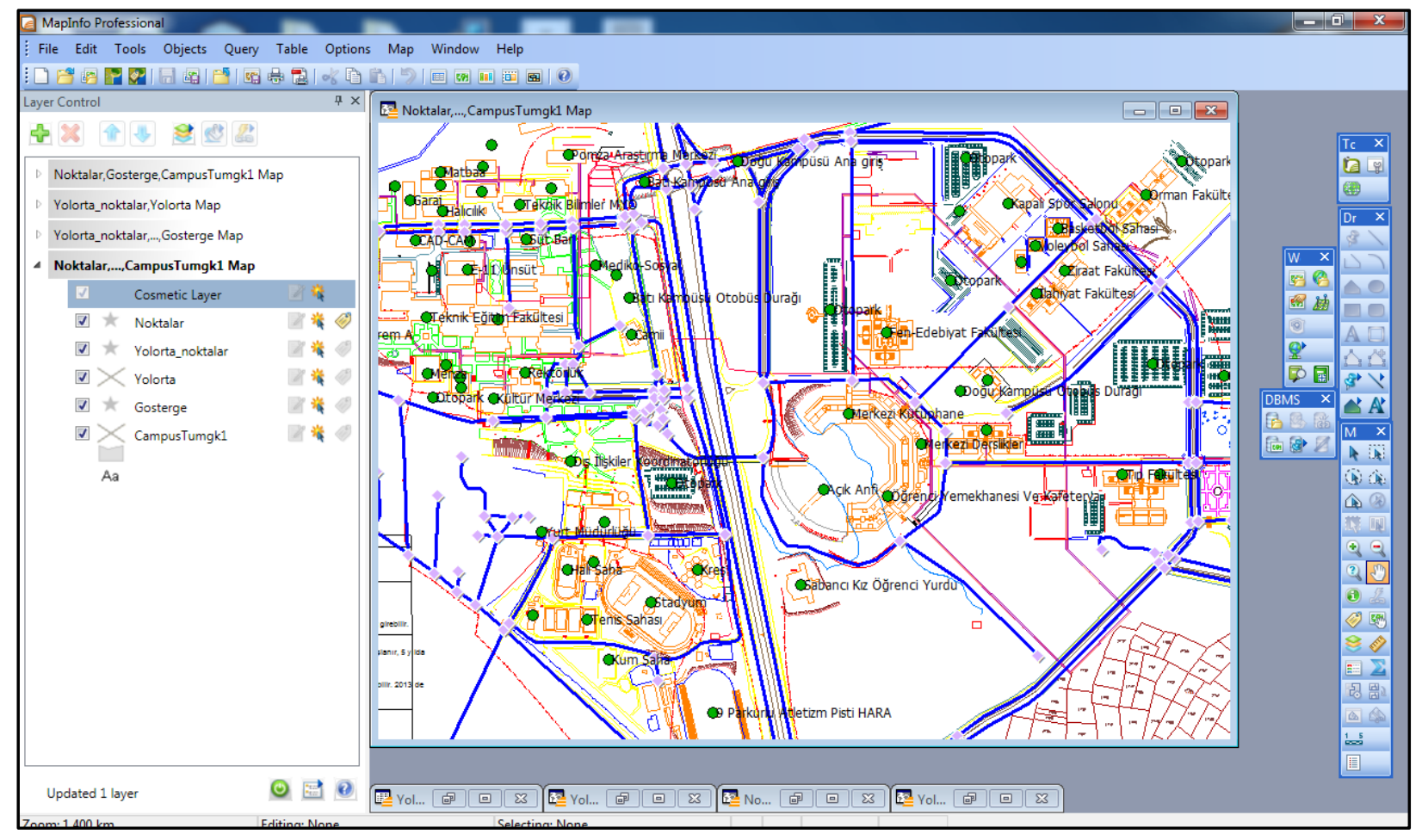

Figure 1. Maplnfo Professional caption 
An Efficient Mapping Tool Development for University Campuses: The Case Study of Süleyman Demirel University

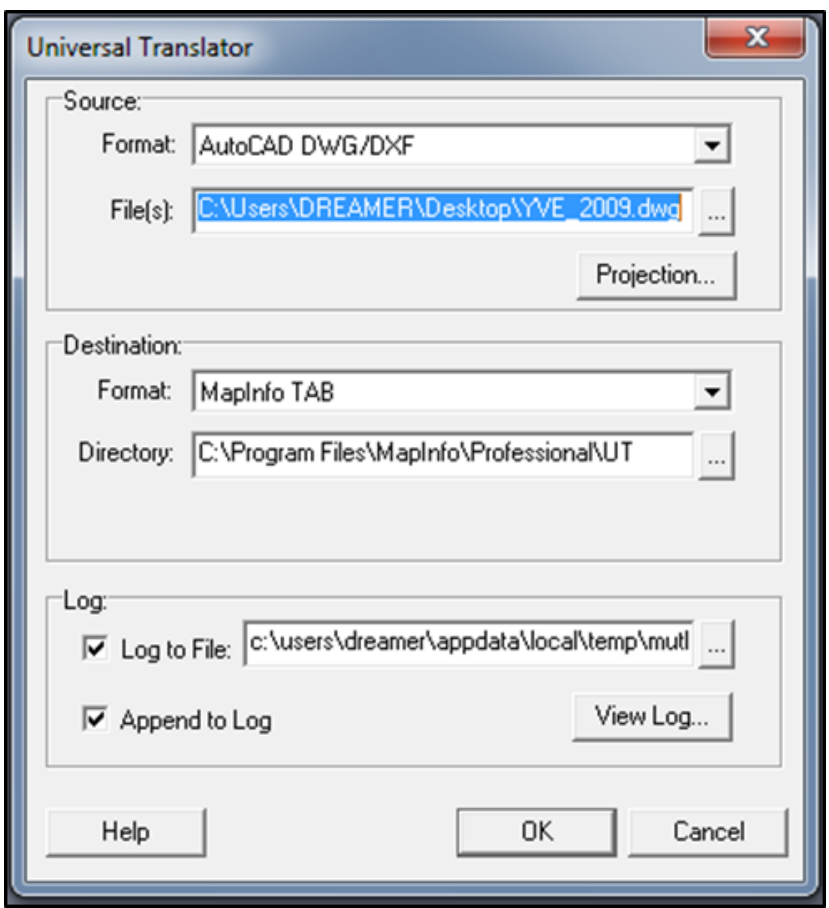

Figure 2. Maplnfo Professional universal translate tool

The file "Kampus.TAB" has been purged of unnecessary data and integrated into a single layer (campus layer), and a simple file has been popped up and provided. In order to see the names of the buildings in the campus area, the points layer has been created. This layer would also be used to determine the starting and ending points of the users while getting direction. In addition, the points layer has been demonstrated in Figure 3.

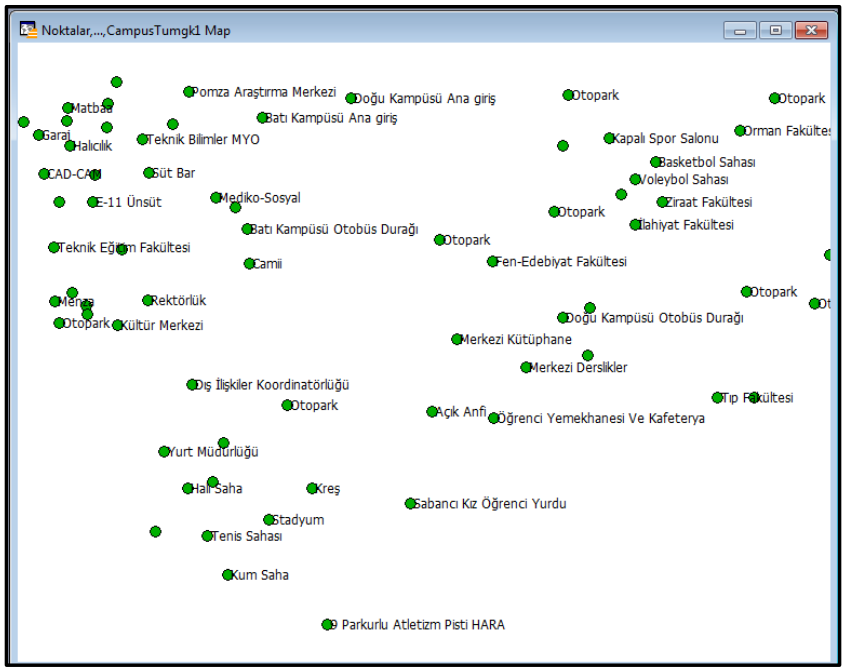

Figure 3. Points layer

\section{RESULTS}

After the SDU Campus Maps map was transferred to Visual Studio, the interface was created. An image from the SDU Campus Maps program has been given in Figure 4.

In order to control whether the developed tool has been run efficiently or not, two inquires has been tested and applied in the application of SDU Campus Maps. These inquires has been given in Figure 5 and Figure 6.

The first inquiry has been inquiry\#1 (Figure 5):

Starting point: Faculty of Arts and Sciences

Destination: Vocational School of Technical Sciences

The second inquiry has been inquiry\#2 (Figure 6):

Starting point: Rectorate

Destination: Faculty of Arts and Science 
An Efficient Mapping Tool Development for University Campuses: The Case Study of Süleyman Demirel University

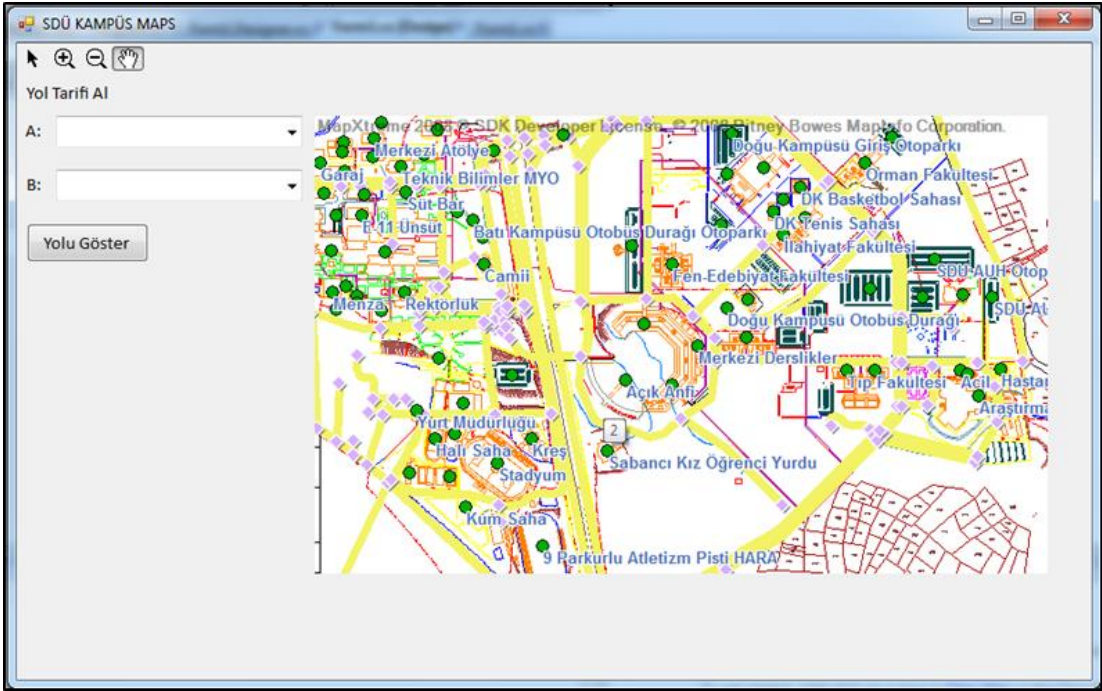

Figure 4. SDU campus maps

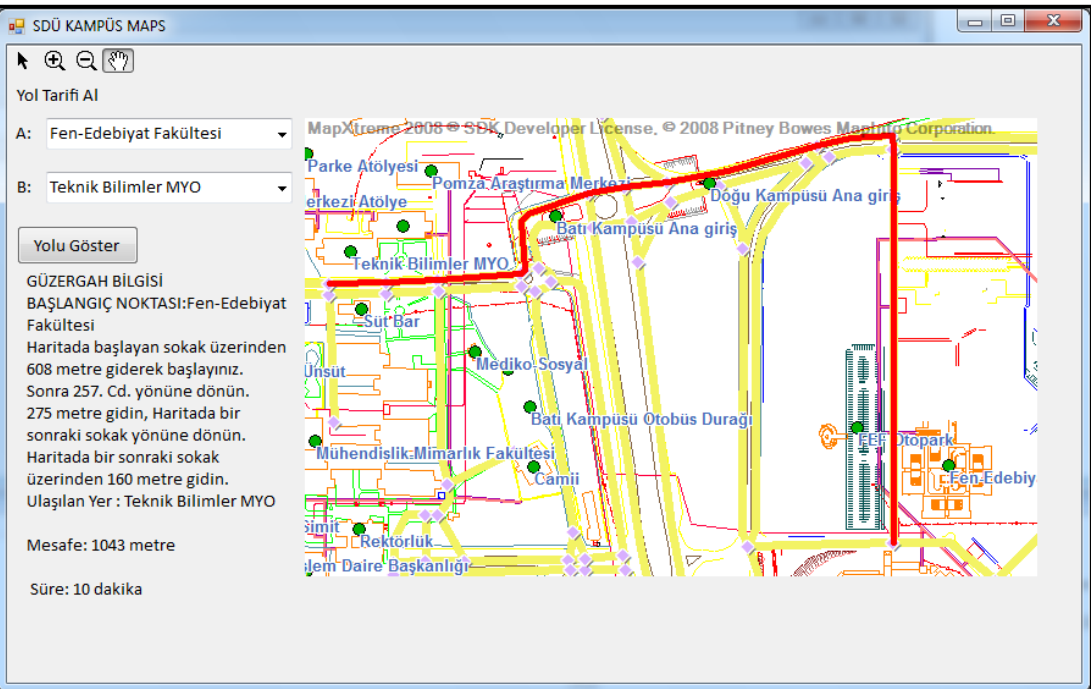

Figure 5. The result of inquiry\#1

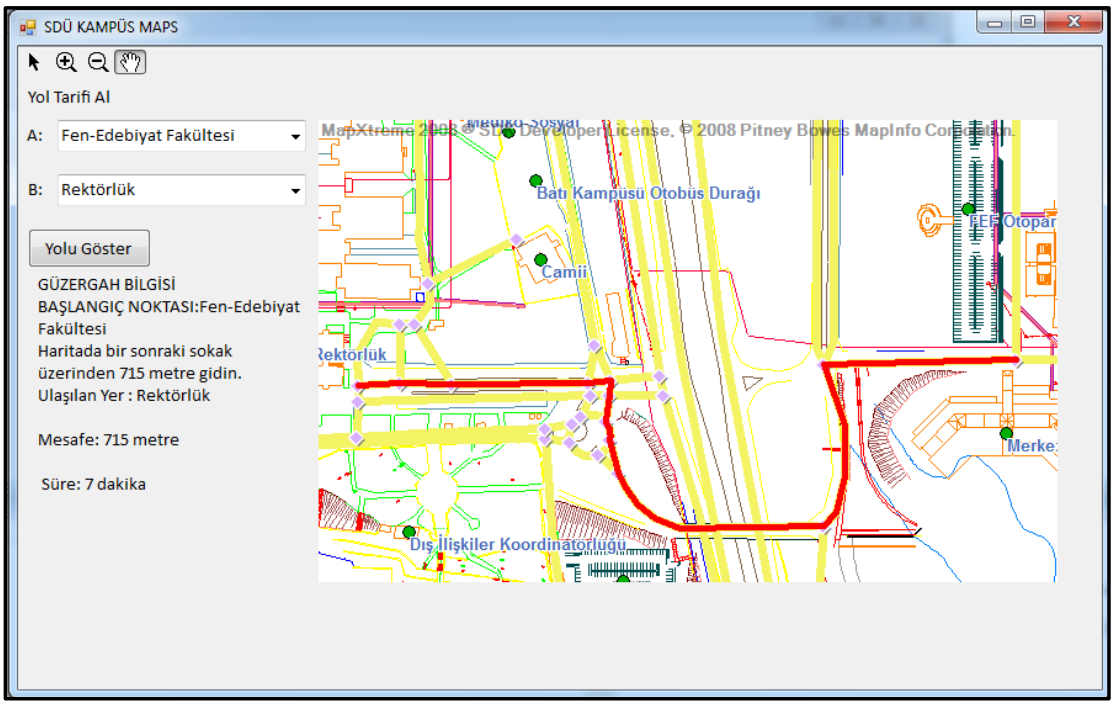

Figure 6. The result of inquiry\#2 


\section{CONCLUSIONS}

Universities are the most important higher education institutions that conduct education and research in our country, as in many countries today. These institutions can sometimes have a very complex structure. This complexity poses a challenge to new incoming students and university visitors. In order to eliminate such problems, systems that can describe one point on the campus from another point are needed. For this purpose, an information system has been designed for Süleyman Demirel University and a campus information system has been realized by utilizing today's information technology. The feature of this system, called SDU Campus Maps, is that directions can be obtained from one building within the campus to another. The most important point here is that the road described is the shortest route on this route.

Since University Campuses are generally large, someone who does not know the campus will definitely spend more effort trying to find the place they are looking for than the effort spent on going to the places they know. In the information age we live in, there is an absolute need for location-based information systems for campuses. Studies on this subject in many universities around the world show that there is a rapid development in this direction. Based on this idea, an information system was designed and implemented for Süleyman Demirel University. The system called SDU Campus Maps has been developed in parallel with the basic philosophy of geographic information systems.

The software to be used in the Campus Geographic Information Systems project to be realized should be determined according to the needs. It should be noted that the software to be used should be in a structure that allows it to work with big data, to be easy to use, fast, to process different spatial data, to be created from interfaces that are related to other systems, and that allow querying and transferring the results to the map. Maplnfo, a product of Pitney BOWES, is considered sufficient in this sense. As a result; with this study, a pilot project application was carried out in the design and implementation of campus information systems, which are geographic information systems, and the efficiency of the system was tested in terms of getting directions from one point in the campus to another point.

\section{REFERENCES}

Akay, A., Bensghir, T.K. (2007). Turkish applications of geographic information systems in local governments. Ankara: Bizim Büro Publishing House.

Arca, D. (2012). Geographic information system and remote sensing in disaster management. Karaelmas Journal of Science and Engineering, 2(2): 53-61.

Aydınoğlu, A.Ç., Yıldız, S.S., Demir, E., Ateş, S. (2010). How geographic information systems work. Journal of Science and Technology, 514: 52-57.

Church, R.L. (2002). Geographical information systems and location science. Computers and Operations Research 29 (6), 541-562.

Çağatay, U. (2012). An evaluation on urban real estate value maps and application areas. Journal of Economics and Management Studies, 1(1): 25-41.

Çelik, B. (2011). Karahan Tepe: A new cultural centre in the Urfa Area in Turkey. Documenta Praehistorica, 38:241254.

Çömert, R., Bilget, Ö., Olcay, F., Aksoy, T., Şenöz, E., Çabuk, A. (2016). Historical development of geodesign and its relationship with geographic information systems. Eastern Geography Journal, 35: 17-38.

Day, R.W. (2002). Geotechnical earthquake engineering handbook. United States: McGraw Hill.

Fonseca, F.T., Egenhofer, M.J., Agouris, P., Câmara, G. (2002). Using ontologies for integrated geographic information systems. Transactions in GIS, 6(3):231-257.

Gören, S., Ferguson F.J. (2002). CHESMIN: A Heuristic for state reduction in incompletely specified finite state machines. DATE '02: Proceedings of the conference on Design, automation and test in Europe.

Gümrükçüoğlu, M. (2003). Geographic information systems: Meaning, benefits, problems and future. Sakarya University Journal of Science Institute, 7(1): 67-72.

İnan, A., İzgi, E. (2011). Geographical information system, Yıldız Technical University, Istanbul.

Jun, C. (2000). Design of an intelligent geographic information system for multi-criteria site analysis. URISA Journal, 12: 5-17.

Koçak, H. (2009). An evaluation of the effects of geographical information systems on increasing the quality of urban life. Dumlupınar University Journal of Social Sciences, 25: 141-148.

Nurlu, E. (2000). Geographic information system in environmental management. Journal of Muğla University Institute of Social Sciences, 1(1):147-153.

Pandey, J., Pathak, D. (2014). Geographic information system. New Delhi: TERI press.

Sönmez, N. K., Sarı, M. (2004). Geographic information systems fundamentals and application areas. Derim Magazine, 21(1): 54-68.

Tecim, V. (1999). A new development in information technologies: Its place between geographic information systems and information systems. Journal of Dokuz Eylul University Faculty of Economics and Administrative Sciences, 14(1): 1-12. 
An Efficient Mapping Tool Development for University Campuses: The Case Study of Süleyman Demirel University

Turoğlu, H. (2000). Fundamentals of geographic information systems. Istanbul: Acar Printing.

United Nations (2000). Handbook on geographic information systems and digital mapping. New York: United Nations Publication.

Yomralıoğlu, T. (2000). Geographic information systems: Basic concepts and applications. Istanbul: Akademi Publishing House.
Yomralıoğlu, T. (2003). Geographic Information System Policy. 2003 Scientific Meeting of the Turkish National Geodetic Commission (TUJK): Geographic Information Systems and Geodetic Networks Workshop, 24-26 September 2003, Konya: Selçuk University.

Yomralıoğlu, T. (2010). Geographic information technologies. Journal of Science and Technology, 514: 48-51.

Youd, T.L. (1984). Geological effects-liquefaction and associated ground failure. Geological and Hydrogeological Hazards Training Program, United States Geological Survey Open-File Report, 87-76: 210-232. 